\title{
Medicinal Potential and Scientific Validations of Mallotus philippinensis (Lam.) Muell. Arg. (Kampillaka): A Review
}

\author{
Hewageegana $\mathrm{HGSP}^{1 *}$ and Hewageegana $\mathrm{AU}^{2}$ \\ ${ }^{1}$ Department of Kaya chikitsa, University of Colombo, Sri Lanka \\ ${ }^{2}$ Faculty of Science, University of Colombo, Colombo, Sri Lanka
}

*Corresponding author: Hewageegana HGSP, Department of Kaya chikitsa, Institute of Indigenous Medicine, University of Colombo, Sri Lanka, Email: sujathahgsp@yahoo.com

\section{Research Article \\ Volume 5 Issue 3}

Received Date: May 13, 2021

Published Date: July 23, 2021

DOI: $10.23880 /$ jonam-16000314

\section{Abstract}

Mallotus philippinensis (Lam.) M Arg is one of the endangered plants in the central ecoregion. It belongs to the Euphorbiaceae family. Mallotus philippinensis (Lam.) Muell. Arg. (Family: Euphorbiaceae) is a medicinally important common perennial shrub used in indigenous medicine. It is distributed mainly in the tropical and subtropical regions of the world. Though it is a drug of herbal origin, it has been grouped into one of the eight Sadharana rasa groups [Glands and hairs of Mallotus philippinensis (Kampillaka), Arsenic (Somala), Ammonium Chloride (Navasagara), Cowri (Kaparda), Amber (Agnijaara), Red Oxide of Mercury (Girisindoora), Cinnabar (Hingula), Litharge (Muddaarashringa)] in Rasa-shastra (Ayurveda study of minerals and metals) of Ayurvedic pharmacopoeia. M. philippinensis is included in Virecana ghana (group of medicinal plants or products use to purgation therapy) of Ayurveda medicine. Especially roots, fruits (also as fruit powder) and the leaves are used for medicinal purposes. Leaves are bitter and have a cooling and appetizing nature. The glands/hairs of the fruit and the leaves are recommended for dermal problems. So far, scientific studies have been carried out to prove and look-into the pharmacological activities of M. philippinensis. Here, an attempt is taken to summarize the distribution, morphology, Ayurveda and traditional uses, and scientific investigations on M. philippinensis. Researchers have scientifically proven the Antimicrobial activity, Hepatoprotective activity, Anti-Leukemic activity, Anti-HIV activity, Anti-inflammatory activity, Anti-filarial activity, Analgesic and hypnotic activity, Antiproliferative activity, Antifertility activity, Purgative activity and Anthelmintic activity and Antiallergic activity against different parts of the M. philippinensis.

Keywords: Mallotus philippinensis (Lam.) Muell. Arg; Physico-Chemical Parameters; Phytochemicals; Health Benefits; Pharmacological Activities

\section{General Introduction}

Mallotus philippenesis (Lam.) M. Arg. commonly known as Kampillaka, is one of the endangered plants of central ecoregion in India. It belongs to the Euphorbiaceae family Mallotus philippinensis (Lam.) Muell. Arg., (M. philippinensis) is a woody, large genus multipurpose medicinal tree (Wealth of India, 2003). Shrubs distributed mainly in the tropical and subtropical regions of the world with around 20 species in India.

\section{Scientific Classification (Table 1)}

\begin{tabular}{|c|c|}
\hline Kingdom & Plantae \\
\hline Division & Magnoliophyta \\
\hline Class & Magnoliopsida \\
\hline Order & Euphorbiales \\
\hline Family & Euphorbiaceous \\
\hline Genus & Mallotus \\
\hline Species & philippinensis \\
\hline
\end{tabular}

Table 1: Classification. 


\section{Journal of Natural \& Ayurvedic Medicine}

\section{Vernacular Names}

- Indian language

- Assam: Lochan, Gangai, Puddum

- Bengali: Kamlagudi, Kamala gundi

- Gujarati: Kapilo

- Hindi: Kabila, Sindur, Kamala, Kambhal, Kambila, Raini, Rohni, Roini,

- Kannada: Chandrahettu, Kapila, Kapilathettu

- Kashmiri: Kaimbil, Kameelak

- Malayalam: Kampippala, Kampipalu, Kapila, Chenkolli, Kuramatukka, Ponni

- Marathi: Sinduri, Shendri, Kapila

- Orissa: Kmalagundi

- Punjabi: Kamila, Kambal, Kumila, Kampila

- Tamil: Kungumam, Kurangumanjanatti, Kabilam, Kopilapodi

- Telugu: Kampillamu, Chendiramu, Kunkuma

- Tulu: Ponne

- Urdu: Kamila, Kalileh

- Arabic: Kampileh

- Burma: Tanthieden, Tawtheeteng, Tawthidin

- Ceylon: : Kapila

- English: Kamala, Monkey face Tree

- Nepal: Safed mallata, Sinduria

- Persia: Kampileh, Kanbela

Though it is a drug of herbal origin, it has been grouped into one of the eight Sadharana rasa groups [Glands and hairs of M. philippinensis (Kampillaka), Arsenic (Somala), Ammonium Chloride (Navasadara), Cowrie shell (Kaparda), Ambergris (Agnijara), Red Oxide of Mercury (Girisindoora), Cinnabar (Hingula), Litharge (Muddaarashringa)] in Rasa-shastra (Ayurveda study of minerals and metals) of Ayurvedic pharmacopoeia. Kampillaka ( $M$. phillipensis): Charaka mentioned it under phalini dravya while, Acharya Sushruta quoted it under Shyamadi varga [1]. Acharya Vagbhata mentioned it in virechana ghana (group of medicinal plants use for purgation). Bhavamishra [2] cited it as a useful medication for bleeding, diabetes and urinary stones. Dhanvantari Nighantu praised it as a valuable remedy for flatulence, worms, constipation, ascites due to kapha and cough etc.

\section{Ayurveda properties}

Rasapanchaka [Five factors contain in dravya (medicinal plants)]. A drug performs its therapeutic actions with the help of Rasapanchaka (properties of medicinal plant) i.e. Rasa, Guna, Virya, Vipaka and Prabhava. There is no controversy regarding its Rasa Panchaka among Nighantus.

They all have described it as follow:-

Rasa: Katu, Amla
Guna: Laghu, Ruksha, Tikshna Ushna

Virya: Ushna

Vipaka: Katu

Prabhava: Krumighna

Dosha Karma: Kapha Vata shamaka, Rechaka, Krimighna, Vibhedi, Ama-pachana Deepana and Asrajit.

Rogagnata: Krimi, Twak roga, Vruna, Vibandha, Gulma, Udara, Arshas, Shula, Jvara, Prameha and

Prabhava: Recaka. Bhavamishra [2].

\section{General Uses of Mallotus philippinensis}

According to Ayurveda, leaves are bitter, and have a cooling and appetizing nature. All parts of plant like glands and hairs from the capsules or fruits are used. It can be quite useful for expelling tapeworms. Kamala is also used as an oral contraceptive. The powder and a few other parts of kamala are also used in external applications to promote the healing of ulcers and wounds. M. philippinensis fruit is purgative, detergent, carminative, alexiteric and useful in treatment of bronchitis, abdominal diseases, spleen enlargement etc and if taken with milk or curd (yoghurt), it can be quite useful for expelling tapeworms. They are used to treat parasitic affections of the skin like scabies, ringworm and herpes [3].

All parts of the tree can be applied externally to treat parasitic infections of the skin. The fruits and bark have been reported to be used medicinally to treat stomach ulcers and tapeworm. A decoction of the leaves is used in the treatment of diarrhea. Root scrapings are chewed with a betel mixture as a contraceptive for women [4].

The glands/hairs of the fruit and the leaves of $M$. philippensis are recommended for dermal problems and the oil prepared with fruit powder and the gingili oil is better for wound healing [5]. Powder of M. philippinensis (glands/ hairs of the fruit) properly mixed with coconut oil can be applied for Pama kushtha (skin lesion with white and red, black, itchy eruptions), burning wounds and other wounds [6]. M. philippensis is used to dress wounds and burns. Oil of $M$. philippensis cleanses chronic infected wounds. In dermatitis, especially in oozing type, $M$. philippensis is considered to be a valuable remedy [7]. In addition, tincture of M. philippensis is prescribed for worm treatments as it contain purgative properties other than the vermicide activity [8]. The dose of $1.5 \mathrm{~g}-2 \mathrm{~g}$ of fruit powder with Guda (Jaggery of sugarcane) is better for intestinal worms [8]. Along with this medicinal importance, this plant is used against human pathogens including Helicobactor pylori, anti-inflammatory activity, antiallergic, anti-HIV activity, and many more [9]. When the fruit powder is mixed with Shatadautagrita (ghee prepared by 100 times washing) is better for hair falling. Also M. philippensis contains blood purifying and aphrodisiac properties $[3,6]$. The crude powder of kamala obtained as a 


\section{Journal of Natural \& Ayurvedic Medicine}

glandular pubescence from the exterior of fruits is found to be useful in case of hook worms, round and earth worms, anthelmintic activity. The drug was found to be $100 \%$ effective against tapeworms [10].

Fruit powder of M. philippinensis is one of the main ingredients of Vipadikahara grita taila is medicated oil which was mentioned in Caraka Samhita under the Kushtha chikitsa as a treatment for five types of skin diseases-Vipadika, Carma kushta, Eka kushtha, Kitibha and Alaska [11].

M. philippinensis is taken as a drug itself: Its oil is indicated in dermal problems and non-healing wounds. $M$. Philippensis root, bark, leaves and glands/hairs (red powder covering the fruits) have been used in Ayurveda for many years, for the treatment of variety of disease conditions. Some of them are: medicinal oils prepared using glands/ hairs of the fruit powder of M. Philippensis and they are prescribed for dermal problems, glands/hairs of the fruit and leaves of M. Philippensis were commonly recommended for dermal problems in Sri Lankan, the glands and the hairs of the fruits are used to expel intestinal worms, and also as a purgative. In addition, leaves are used externally for different types of skin infections and infected wounds [5]. It's oil is indicated in dermal problems and non-healing wounds [12]. The glands/ hairs of the fruit mixed with coconut oil are used to dress wounds and burns. The oil of Kampillaka cleanses the chronic infected wounds. In dermatitis, especially of oozing type, Kampillaka is considered to be a valuable remedy [7]. Generally, studies have suggested antibacterial, anticancer, anthelmintic, antifertility, anti-inflammatory, anti-cancer, antispasmodic, astringent, contraceptive, laxative, immunomodulatory, vermifuge, and purgative and vulnerary properties [13]. All parts of the tree can be applied externally to treat parasitic infections of the skin. The fruits and bark have been reported to be used medicinally to treat stomach ulcers and tapeworm. A decoction of the leaves is used in the treatment of diarrhea. Root scrapings are chewed with a betel mixture as a contraceptive for women [4].

Even though, the glands/hairs of the fruits are mentioned, they are not freely available in the markets. Accordingly, Kampillaka is useful both internally as well as externally. Pharmaco-dynamic properties of M. philippinensis are, well described in Charaka and Sushruta Samhita: Ayurvedic classics of ancient traditional medicine of India but, it was not much used in recipes of traditional medical system of Sri Lanka respectively.

- Distribution: This plant is widely distributed in the tropical and sub-tropical region including all over the Punjab, Uttar-Pradesh, Bengal, Assam, Burma, Singapore, and from Sind south wards to Mumbai and Ceylon. It is also reported as growing in China, the Malaya Islands,
Australia, Pakistan and Andaman Islands. Natural reproduction takes place by seeds which fall to the ground in the beginning of the hot season and germinate in the rainy season. Artificial propagation is done by sowing fresh seeds in April. The more vigorous seedlings are ready for transplanting during the first year, smaller ones may be kept for another year in nursery. The tree also reproduces from root suckers but the growth is very slow. It can withstand considerable shade and is frost-hardy and drought-resistant [14]. M. Philippensis is a common perennial shrub, medicinally important plant used in indigenous systems of medicine. Trees are small to medium-sized monoecious in nature, up to $25 \mathrm{~m}$ tall and with a bole up to $50 \mathrm{~cm}$ in diameter, but usually much less in number. The growth is comparatively slow, mean annual girth increment being reported in India $0.65 \mathrm{~cm}$, and mean girth after 16 years less than $15 \mathrm{~cm}$. In the Philippines a mean annual diameter increment of $1.4 \mathrm{~cm}$ has been recorded for M. philippensis trees in the diameter class $10-20 \mathrm{~cm}$. In India established $M$. philippensis is frost-hardy and resistant to drought and it coppices well and is capable of producing root suckers. M. philippensis is not resistant to fire [15]

- Leaves: Alternate, ovate-lanceolate, 8-22 x 3-8 cm, 3 -nerved at base, glabrous above, pubescent and with numerous red glands beneath; petiole bearing two small glands near apex, borne on long stalks, size about 5-20 cm long [16]. Leaves simple, more or less leathery, ovate to lanceolate, cuneate to round with two glands at base. Leaves are mostly acute or acuminate at apex, conspicuously 3-nerved, hairy and reddish glandular beneath, petiole size 1-4 $\mathrm{cm}$ long, puberulous and reddish-brown in color.

- Flowers: Male flowers in terminal and axillary position, 2-10 cm long, solitary or fascicled paniculates spikes, each flower is with numerous stamens, small and in erect terminal spikes forming elongated paniculate racemes male flowers are yellow in colour, in 7-15 cm long. In the M. Philippensis, flowers from march to April and fruits mature in July-August $\mathrm{m}$. phil. has extra floral nectarines attracting ants [16]. Female flowers have spikes or slender racemes, each flower with a stellate hairy, 3 celled ovaries with 3 papillose stigmas, ovary covered with red glands. Female flowers in erect $5-9 \mathrm{~cm}$ long, long spikes:

- Fruits: Fruit is a depressed-globose, round, 3-lobed capsule, 8-10 $\mathrm{mm}$ in diameter; 3-seeded stellate; puberulous; covered with abundant orange or reddish glandular granules; bright red powder. Fruits are 5-15 $\mathrm{mm}$ and densely covered with redid- brown, powdery substance and minute hairs which are easily rubbed 


\section{Journal of Natural \& Ayurvedic Medicine}

out [16]. Fruits contain Rottlerin (reddish yellow resin) $47.80 \%$ fixed oil $5.83-24 \%$ mallotoxin, kamalin, Oleic lauric, myristic, palmitic acid, stearic acid, crotoxigenin, rhammoside, octa casanol, iso rottlerin, rottlerin, homorottlerin tannins, citric acid and oxalic [13].

- Seeds: sub globose and black in color, 3-4 $\mathrm{mm}$ across seeds $4 \mathrm{~mm}$. in diameter, sub globose, thick, black in cooler and about 7000 mounds can be collected annually in India [16]. Mature fruits have glandular hairs and they collected as reddish brown powder. It is one of the common plants used in Indian system of medicine. Various parts of the plant are used in the treatment of skin problem, bronchitis, antifungal tapeworm eyedisease, cancer, diabetes, diarrhea, jaundice, malaria, urinogenital infection etc. In dispersing swellings of the joints from acute rheumatism and of the testes from suppressed gonorrhea, It also shows anti-oxidant, insecticidal/pesticidal, anti- microfilaria, anti-lithic, hepatoprotective activities [17]. Specially roots, fruits and fruit powder and the leaves are used for medicinal purposes: treatment of, cancer, diabetes, bronchitis, skin problem, antifungal, tapeworm, eye-disease, diarrhea, jaundice, malaria, urinogenital infection etc [18].

\section{Common Adulterants}

Glandular hair powder of M. philippinensis is commonly adulterated with Annato dye (Bixa orellana Linn.), ferric oxide, brick dust, and ferruginous sand. Casearia tomentosa (stem bark powder), Carthamus tinctorius (flower powder), Ficus benghalensis (fruit powder), and Flemingia macrophylla (hairs of fruits) are also reported to be used as adulterant or substitute of Kampillaka [19].

But there are so many disadvantages in adulterants

- Adulteration is one of the greatest drawbacks in promotion of herbal products.

- Adulteration can cause deterioration and degradation of products.

- It can cause denaturation of product and may destroy the active constituents of drugs.

- It leads to increase the cost of the products.

- Efficacy of drug reduces or it may take longer time to show its action.

- It can alter the dosage form and nature of drugs.

- It can produce adverse effects [20].

\section{Identification method of Mallotus philippinensis powder}

- For determining its genuineness it should be dropped over the water surface. The pure Kampillaka floats on the water and impurities like, sand, mud, brick powder etc. settles down at the bottom.

- The wet powder of Kampillaka may produce yellow line on white paper when rubbed with fingertip.

- Kampillaka powder when put on fire, it produces sparking.

- It is very soft, crimson coloured powder

In traditional medicine in Sri Lanka, normally use glands/ hairs of M. Philippensis fruit for internal preparations as well as external preparations such as oils for skin disorders.

Though the glands/ hairs of the fruit are preferred, glands/hairs of $M$. Philippensis fruit is not available in the market. According to Hewageegana, et al. [21], following findings were revealed (a) qualitative similarities in phytochemical constituents in the ethanolic extracts of the leaves and glands/hairs, (b) some differences in TLC fingerprint profiles and (c) significant differences in amount of cold and hot ethanol extractable matter of the leaves and glands/hairs of M. Philippensis fruit were shown. Hence, for external medicinal preparations with external uses, leaves can be used on behalf of the glands/hairs of M. Philippensis fruit.

\section{Physico-chemical parameters of glands/hairs of fruits and leaves of Mallotus Philippensis}

It is important to identify the physico-chemical parameters of glands/ hairs and leaves of M. Philippensis and the TLC fingerprint profiles of M. Philippensis. Total ash, acid insoluble ash and water soluble ash contents, water extractable matter (hot and cold), ethanol extractable matter (hot and cold), moisture content were determined according to methods described in guide lines of WHO [22] guidelines.

\section{$>$ Ash content}

Ash consists mostly of metal oxides, salts and inorganic constituents. Ash value is a criterion to judge the identity and purity of crude drugs [23]. Acid insoluble ash indicates contamination with silica. Water soluble ash is that part of the total ash content, which is soluble in water. It is a good indicator of the water soluble salts in the drug [24]. Total ash as well as acid insoluble ash content of the leaves of $M$. Philippensis were significantly higher than that of the glands/ hairs of the fruit [21].

Extractive value is useful for the evaluation of a crude drug as it gives an idea about the nature of chemical constituents present in the drug. According to Velanganni and Kadamban [18], hexane, chloroform and ethanol extractive matter in leaves of M. Philippensis were $13.0 \%, 9.0 \%$ and $10.5 \%$ respectively. Results of extractable matter parameters are expressed in Fig 1 and 2 respectively according to Hewageegana, et al. [21] and some studies showed, amount of ethanolic extractable matter was significantly lower than 
$10.5 \%$.

Extractive matter of glands/hairs of the fruit was significantly higher than that of cold and hot ethanol extractive matter of the leaves. In comparison with the hot water extract, much less amount of extractable matter was observed in cold water extract of glands/hairs of the fruit and the leaves. Therefore, more chemical constituents appear to dissolve in the hot water and ethanolic extracts than the cold water extract [21] (Figure 1).

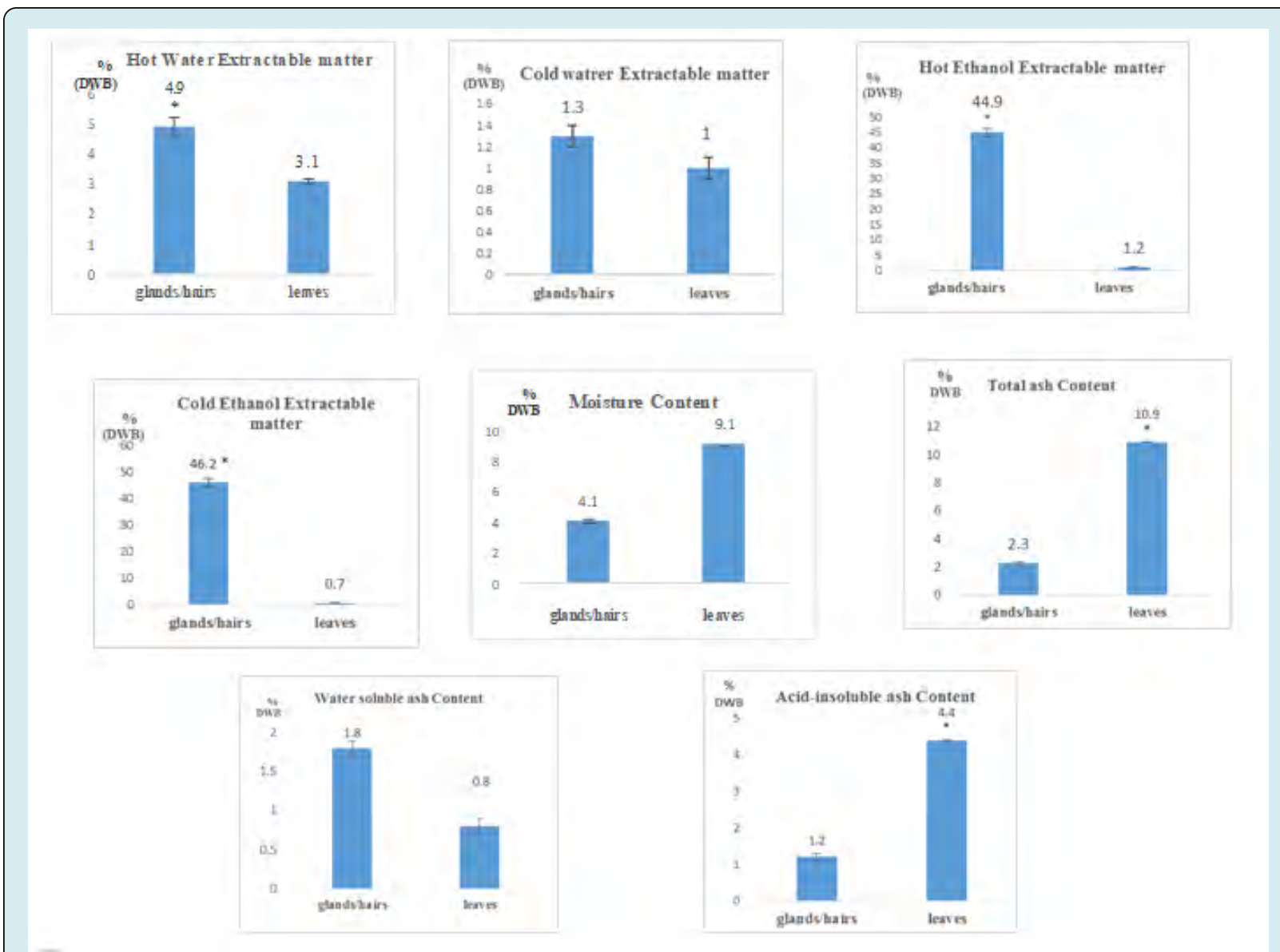

Figure 1: Physico-chemical parameters of Mallotus Philippensis (Lam.) Muell Arg. Glands/hairs and leaves.

\section{Phytochemical screening of glands/hairs of fruits and (leaves of Mallotus Philippensis}

Phytochemical constituents present in plants are good indicators of their medicinal value. As shown in Table 1, important chemical constituents were present in water extract (both hot and cold) and ehanolic extract (both hot and cold) of the leaves and glands/hairs of the fruit of $M$. Philippensis according to Hewageegana, et al. [21].

Though the glands / hairs of the fruits are mentioned as the medicinally rich part of the plants according to Ayurveda texts. If the leaves and glands/hairs of the fruits of M. Philippensis have similar properties leaves can be used in place of glands/ hairs in above preparations. Phytochemical screening of stems yielded carbohydrates, amino acids, flavonoids, gum, oil and resins, proteins, phenolic groups, saponins, steroids, tannins and terpenoids [18]. Phytochemical screening of fruits yielded carbohydrates, proteins, phenolic compounds, tannins, flavonoids, alkaloids, saponins and steroids [25]. Antioxidant property of $M$. Philippensis are present in extractives of fruits and bark. Extract of fruits of kamala from the glands and hairs yield the crystalline compound rottlerin. Its fruits contain Rottlerin (reddish-yellow resin) 47.80\% fixed oil, 5.83-24\% mallotoxin, kamalin oleic, lauric, myristic, palmitic acid, stearic acid, crotoxigenin, rhamnoside, octacosanol, iso-rottlerin, rottlerin, homorottlerin, tannins, citric, oxalic acid $[13,26]$ (Table 2 ). 


\begin{tabular}{|c|c|c|c|c|c|c|c|c|}
\hline \multirow{2}{*}{$\begin{array}{c}\text { Type of } \\
\text { phytochemicals }\end{array}$} & \multicolumn{4}{|c|}{$\begin{array}{l}\text { Presence or Absence of phytochemicals in } \\
\text { glands/ hairs }\end{array}$} & \multicolumn{4}{|c|}{$\begin{array}{c}\text { Presence or Absence of phytochemicals in } \\
\text { leaves }\end{array}$} \\
\hline & (HWE) & (HEE) & (CWE) & (CEE) & (HWE) & (HEE) & (CWE) & (CEE) \\
\hline Phenolic compounds & - & $\square$ & - & $\square$ & $\square$ & $\square$ & $\square$ & $\square$ \\
\hline Saponins & $\square$ & - & $\square$ & - & $\square$ & - & $\square$ & - \\
\hline Flavanoids & - & $\square$ & - & $\square$ & - & - & - & - \\
\hline Tannins & - & $\square$ & - & $\square$ & $\square$ & $\square$ & $\square$ & $\square$ \\
\hline Alkaloids & - & $\square$ & - & $\square$ & $\square$ & $\square$ & $\square$ & $\square$ \\
\hline Coumarin & $\square$ & $\square$ & $\square$ & $\square$ & $\square$ & $\square$ & $\square$ & $\square$ \\
\hline Steroids & $\square$ & $\square$ & $\square$ & $\square$ & $\square$ & $\square$ & $\ddot{O}$ & $\ddot{O}$ \\
\hline
\end{tabular}

Table 2: Preliminary phytochemical screening studies of Mallotus Philippensis (Lam.) Muell Arg. Glands/hairs and leaves.

$\square$ Presence

HWE-Hot Water Extract CWE-Cold Water Extract

HEE-Hot Ethanol Extract $\quad$ CEE-Cold Ethanol Extract

Phenolic compounds possess biological properties such as antiaging, anticarcinogenic, anti-inflammatory, antiatherosclerosis, cardiovascular protection and improvement of endothelial function, as well as in cell proliferation activities [27]. Natural antioxidants mainly come from plants in the form of phenolic compounds such as flavonoids, phenolic acids, etc [28]. When considering the amount of tannins, bark contains 6-10\% and leaves contain a lesser amount. Tannins interfere with protein synthesis. Flavonoids are hydroxylated phenolic substances synthesized by plants in response to microbial infection and exert antimicrobial activity against a wide array of microorganisms in vitro [29].
The plant extracts also contain saponins which produce inhibitory effect on inflammation [30]. Therefore, various classes of secondary metabolites play a major role in therapeutic properties of M. Philippensis.

\section{Thin Layer Chromotograply (TLC) fingerprints for glands/hairs of fruits and leaves of Mallotus Philippensis}

Thin layer chromatography (TLC) is a chromatographic technique used to separate non-volatile mixtures [31] (Figures 2-4).

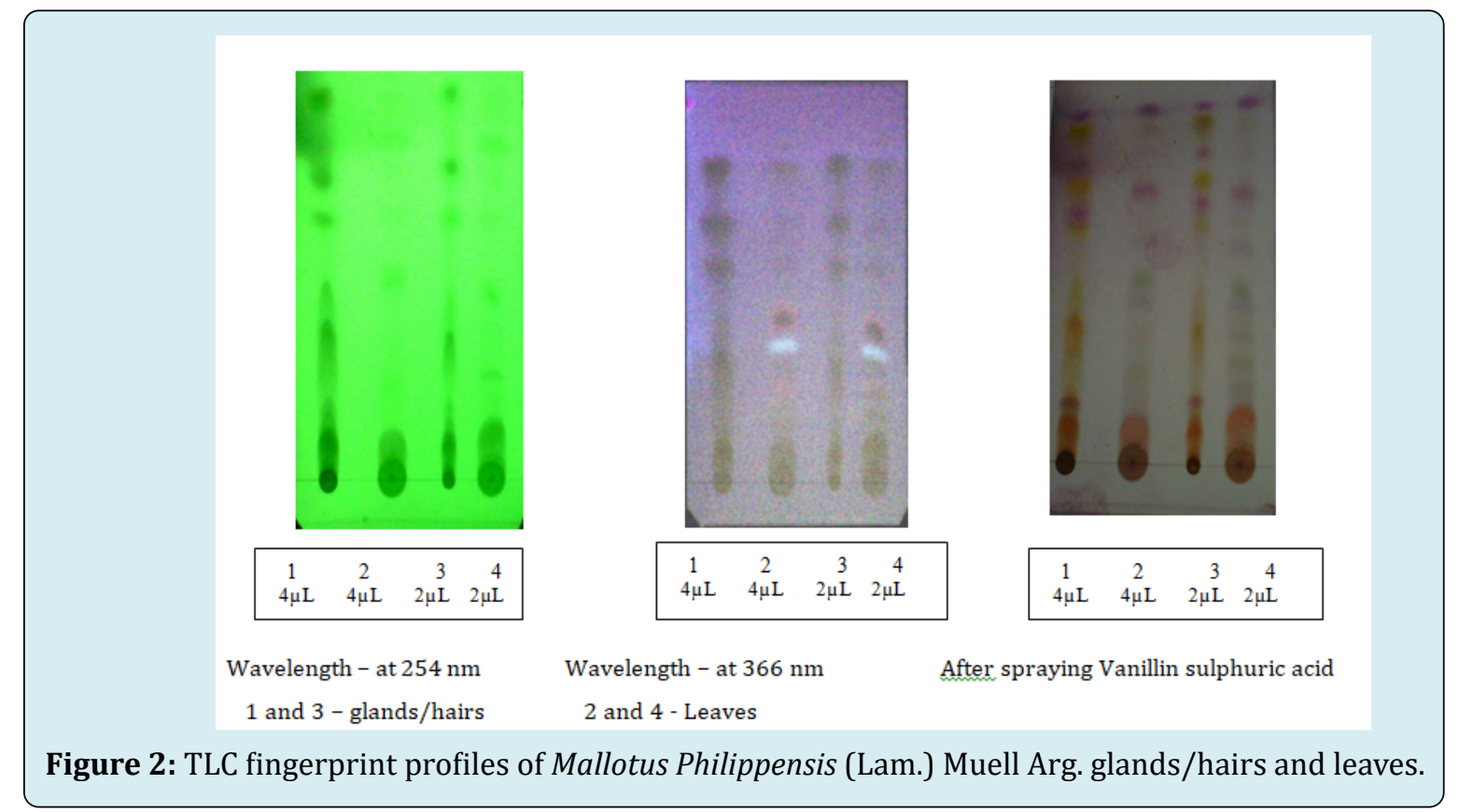

Densitogram is a way of measuring the darkness of a the spot. spot-the more material that the instrument sees, the darker 


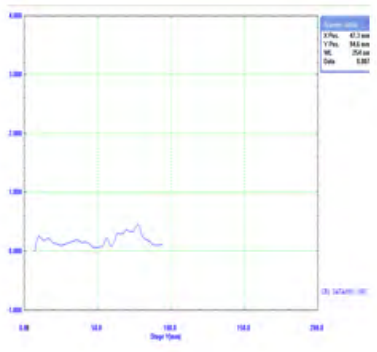

(a)

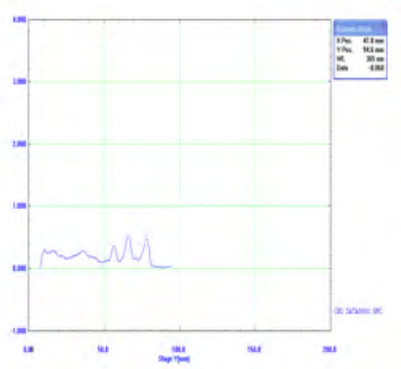

(b)

Figure 3: TLC- densitogram fingerprint of Red Powder of Mallotus philippinensis at (a) $254 \mathrm{~nm}$ and (b) $366 \mathrm{~nm}$.

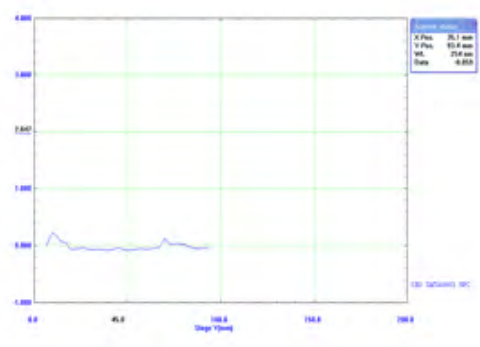

(a)

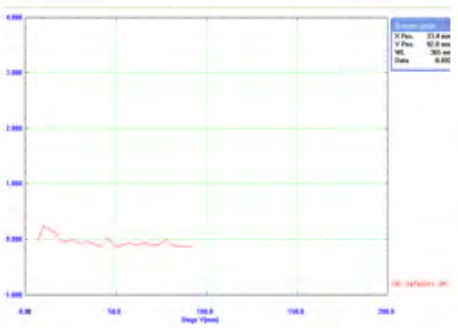

(b)

Figure 4: TLC- densitogram fingerprint of leaves of Mallotus philippinensis at (a) $254 \mathrm{~nm}$ and (b) $365 \mathrm{~nm}$.

\section{Pharmacological Studies}

\section{$>$ Antimicrobial Activity of Mallotus philippinensis}

Glandular hair of fruits of Mallotus exhibits significant antibacterial activity against human pathogenic bacteria with MIC ranging $15-20 \mathrm{mg} / \mathrm{mL}$. The fruit extract possesses antibacterial activity without any antifungal potential [32]. The antimicrobial activity of hexane, chloroform and ethanol leaf extract showed significant activity against the human pathogens such as Streptococcus pneumonia, Proteus vulgaris, Pseudomonas aeruginosa, Salmonella typhi, Vibrio species and the fungus Candida albicans. The antimicrobial activity of the tested extracts showed dose dependent activity against all the tested bacteria with the zone of inhibition ranged from 12-26 mm. However, only the ethanol extract showed antimicrobial activity against the tested fungus Candida albicans and with the zone of inhibition ranged from 16-22 $\mathrm{mm}$ [18]. Antimicrobial activity of hexane, chloroform and methanol extracts of stem bark of M. philippinensis was investigated against Escherichia coli, Klebsiella pneumoniae, Pseudomonas aeruginosa, Salmonella typhi and Bacillus subtilis. Except hexane extract, other extracts showed significant antimicrobial activity against tested bacterial species [33]. According to Zaidi and co-workers [34], 70\% ethanolic extract and its constituents of M. philippinensis showed potent antimicrobial activity against Helicobacter pylori. Further, purification of extract revealed that rattler in exhibits potent bactericidal effect with minimal bactericidal concentration (MBC) of $3.12-6.25 \mathrm{mg} / \mathrm{L}$ especially against clarithromycin and metronidazole resistant $H$. pylori strains to prevent further surge in resistant antibiotics.

However, ethanolic extract shows potent antiHelicobacter pylori activity at the concentration of 15.6$31.2 \mathrm{mg} / \mathrm{L}$ against eight $H$. pylori strains. Further purification of extract revealed that rottlerin exhibits potent bactericidal effect with minimal bactericidal concentration (MBC) of $3.12-6.25 \mathrm{mg} / \mathrm{L}$ against different resistant strains of clarithromycin and metronidazole including Japanese and Pakistani strains [34].

Bioassay-directed fractionation of the organic extract of Mallotus philippinensis gave five compounds (1-5), the most active of which against Mycobacterium tuberculosis was a new compound, 8-cinnamoyl-5,7-dihydroxy-2,2-dimethyl-6geranylchromene (1) for which the name mallotophilippen F is suggested. Compound (2), 8-cinnamoyl-2,2-dimethyl-7hydroxy-5-methoxychromene, was isolated from a natural source for the first time, while the remaining three compounds, rottlerin (3), isoallorottlerin $=$ isorottlerin (4) and the so-called "red compound," 8-cinnamoyl-5,7dihydroxy-2,2,6- trimethylchromene (5), had been isolated 
previously from this plant. All compounds were identified by analysis of their spectra including 2D-NMR, which was used to correct the literature NMR spectral assignments of compounds 2-4. The C-13 NMR of 5 is reported for the first time [35].

\section{$>$ Hepatoprotective activity of Mallotus philippinensis}

Hepatoprotective activity of the methanolic extract was studied against various hepatotoxicants - ethanol and carbon tetrachloride in rats. Physical (wet liver weight and volume), biochemical (serum GOT, GPT, ALP, direct and total bilirubin, total protein, cholesterol, triglyceride), antioxidant parameters (CAT, SOD, LPO), functional (thiopentone induced sleeping time) and histopathological changes of livers were assessed in control/standard/extract treated animals exposed to ethanol and carbon tetrachloride hepatotoxicants in rats. When compared to ethanol and carbon tetrachloride toxicant groups the increased thiopentone sleeping time, wet liver weight and wet liver volume were markedly reduced in methanolic extract treated groups. The toxicants induced a rise in the plasma enzyme levels of serum glutamate oxaloacetic transaminase, serum glutamate pyruvic transaminase, total cholesterol, total bilirubin, direct bilirubin, triglycerides, alkaline phosphatase and thiobarbituric acid reactive substance (TBARS) like malonaldehyde. This increase in the enzyme levels were significantly lowered by the extract at $100 \mathrm{mg} / \mathrm{kg}$ and $200 \mathrm{mg} / \mathrm{kg}$. Total protein was found to be decreased compared to normal control group. The toxicant decreased catalase and SOD activities of liver. These activities were significantly increased by the extract of $100 \mathrm{mg} / \mathrm{kg}$ and $200 \mathrm{mg} / \mathrm{kg}$. The histo-pathological changes i.e. fatty changes (steatosis), necrosis etc were partly or fully prevented in animals treated with the extract [36].

Methanolic extract of M. philippinensis leaves decreases the $\mathrm{CCl}_{4}$-induced elevation in biochemical parameters (SGOT, SGPT, SALP, direct bilirubin, total bilirubin, and MDA) on pretreatment at doses $100-200 \mathrm{mg} / \mathrm{kg}$ and also reversed the functional and antioxidant parameters. This study suggests that leaf extract was effective in functional improvement of hepatocytes. Histopathological studies also suggest the hepatoprotective activity of plant [37].

\section{$>$ Anti-Leukemic Activity of Mallotus philippinensis}

Root extract of M. philippinensis was tested on human promyelocytic leukemia HL-60 cell proliferation, cell cycle regulators, and apoptosis in order to investigate its antileukemic effect. Hexane fraction showed promising toxicity against p53-deficient HL-60 cells (IC50 $1.5 \mathrm{mg}$ dry roots equivalent/mL medium) after $72 \mathrm{~h}$ and, inhibition of cell proliferation was preceded by the upregulation of the protooncogenes Cdc25A and cyclin D1 within 24 hours suggesting its antileukemic effect in HL-60 cells [38].

\section{$>$ Anti-viral activity of Mallotus philippinensis}

There is only single study available in literature where the anti-viral activity of this plant has been tested. The methanolic extract of the bark has considerably reduced the infectivity of the Sindbis virus and human poliovirus-1 at concentrations of $200 \mu \mathrm{g} / \mathrm{mL}$ and $50 \mu \mathrm{g} / \mathrm{mL}$, respectively. However, the same extract inactivated the Herpes simplex virus-1 at $100 \mu \mathrm{g} / \mathrm{mL}$ in the dark whereas it was only partially active at concentration of $50 \mu \mathrm{g} / \mathrm{mL}$ in the presence of UV-A radiation and at a concentration of $25 \mu \mathrm{g} / \mathrm{mL}$ in dark and visible light [39]. Initial results of this study indicate that the tree may have the potential to cure viral diseases which demand further investigations for exploration of this property.

\section{$>$ Anti-HIV Activity of Mallotus philippinensis}

Four phloroglucinol derivatives isolated from $M$. philippinensis were tested for their ability to inhibit the activity of human immunodeficiency virus (HIV)- reverse transcriptase. The mode of inhibition of mallotojaponin was found competitive with respect to the template primer, (rA)n (dT)12-18, and noncompetitive with respect to the triphosphate substrate, dTTP. The Ki value of mallotojaponin for HIV-reverse transcriptase was determined as $6.1 \mu \mathrm{M}$ [40].

\section{$>$ Anti-inflammatory activity of Mallotus philippinensis}

Anti-inflammatory activity was evaluated using ethanol (50\%) extract of glandular hairs of $M$. philippinensis fruits in Charles-Foster albino rats. Three animal experimental models were used: (a) carrageenan (acute) (b) turpentine oil induced formalin (sub-acute) induced paw edema (c) granuloma pouch (sub-acute). M. philippinensis at a dose of $200 \mathrm{mg} / \mathrm{kg}$ at $3 \mathrm{~h}$ after their administration showed inhibition of formalin-induced paw edema by $41.60 \%$ and carrageenan-induced paw edema by $55.30 \%$. After 7 days of treatments, M. philippinensis showed $38.0 \%$ inhibition against formalin-induced paw edema and reduced weight of turpentine induced granuloma pouch by $29.6 \%$ and volume of exudates by $26.1 \%$ respectively Daikonya and co-workers [41] have shown inhibition of nitric oxide (NO) production and inducible NO synthase (iNOS) gene expression by a murine macrophage-like cell line (RAW264.7) which was activated by lipopolysaccharide (LPS) and recombinant mouse interferon-gamma (IFN-gamma) using the hexane fraction of acetone extract of M. philippinensis fruits. In addition, suggest the downregulation of cyclooxygenase- 2 gene, interleukin- 6 gene, and interleukin- $1 \mathrm{~b}$ gene expression. It was observed that M. philippinensis fruit extract showed significant anti-inflammatory and analgesic activity against all the rat experimental models which indicates its use in the traditional system of medicine in order to support to reduce inflammation and pain in different pathological condition according to Ganwar [40]. 


\section{$>$ Anti-filarial Activity of Mallotus philippinensis}

The effect of aqueous and alcoholic leaf extracts of $M$. philippinensis (Lam.) Muell was studied on the spontaneous movements of the whole worm and nerve-muscle (n.m.) preparation of Setaria cervi and on the survival of microfilariae in vitro. Both the extracts result in inhibition of spontaneous motility of whole worm and the n.m. preparation of $S$. cervi characterized by initial stimulation followed by depression in amplitude. The tone and rate of contractions remained visibly unaffected. Aqueous extract at higher concentration showed immediate reduction in tone. The concentration required to inhibit the movements of n.m. preparation was $1 / 5^{\text {th }}$ for aqueous and $1 / 11^{\text {th }}$ for alcoholic extract compared to that for the whole worm, suggesting a cuticular permeability barrier. The stimulatory response of acetylcholine was blocked by aqueous extract on whole worm movements. On the microfilariae the $\mathrm{LC}_{50}$ and $\mathrm{LC}_{90}$ were 18 and $20 \mathrm{ng} / \mathrm{mL}$ for aqueous and 12 and $15 \mathrm{ng} /$ $\mathrm{mL}$ for alcoholic extracts, respectively [42].

\section{$>$ Analgesic and hypnotic activity of Mallotus philippinensis}

Analgesic activity was evaluated using ethanol (50\%) extract of glandular hairs of M. philippinensis fruits in CharlesFoster albino rats. Three animal experimental models were used: tail-flick, hot-plate, and acetic acid-induced writhing tests. Results revealed that M. philippinensis at a dose of 200 $\mathrm{mg} / \mathrm{kg}$, showed dose-dependent elevation in pain threshold and peak analgesic effect at $120 \mathrm{~min}$ as evidenced by increased latency period in tail flick method and increased reaction time in the hot-plate test while the reduction in the number of acetic acid-induced writhes by $45.7 \%$. Hypnotic activity was investigated by pentobarbitone-induced hypnotic potentiation in rats and sleeping duration was significantly prolonged in rats treated with M. philippinensis at a dose of $200 \mathrm{mg} / \mathrm{kg}$ [41].

\section{$>$ Antioxidant activity of Mallotus philippinensis}

An acetonic and methanolic extraction of M. philippensis fruits and bark were evaluated for total antioxidant activity, DPPH (2,2-diphenyl-1-picrylhydrazyl radical) scavenging activity, reducing power, total phenolics and tannin contents. The extract of the bark showed the strongest antiradical activity and reduction power [5,43].

\section{$>$ Antiproliferative Activity of Mallotus philippinensis}

Antiproliferative effect was evaluated against Thp- 1 cell lines from the isolated compounds of M. philippinensis fruit extract, in which 4 '-hydroxyrottlerin showed 54\% growth inhibition of Thp-1 cell line. Other isolated compounds were also tested against different fungi and were found to be very effective IC50 values.

\section{$>$ Antifertility Activity of Mallotus philippinensis}

Seed extract of M. philippinensis exhibits adverse effects on different reproductive parameters of female rats. According to the study, extract reduces serum Follicle-stimulating hormone (FSH) and Luteinizing hormone (LH) levels, by affecting hypothalamic/pituitary axis in experimental animals. Reduced level may affect follicular development, quality of ovulated eggs, corpus luteum formation, estrus cycle and maintenance of pregnancy in rats. This antifertility effect of plant extract is supposed to be caused by rottlerin, a phloroglucinol derivative. Acetyl rottlerin may be active, but isorottlerin is either inactive or slightly active. Effect of pure rottlerin can be further studied so as to clarify the potential of phloroglucinol derivatives [44]. Gujral, et al. [45] found that M.philippinensis possesses antifertility effect when tested on rats. The active principle was rottlerin. Many workers also found that powder of fruits reduces fertility in albino rats.

\section{$>$ Purgative Activity and Anthelmintic Activity of Mallotus philippinensis}

A significant purgative effect after an oral dose $(120 \mathrm{mg} /$ $\mathrm{kg}$ ) in rats was assessed from resins isolated from plant. Its effect was evaluated from the weight of faeces as well as from surface area of blotting paper soaked by liquid faeces. The anthelmintic effect on tapeworm was evaluated in albino rats, from the resin of the plant showed lethal effect of $35.69 \%$ and $78.21 \%$ respectively in small intestine in concentrations 60 and $120 \mathrm{mg} / \mathrm{kg}$ respectively $[46,47]$.

The M. philippensis powder was tested for anthelmintic activity. Aqueous, ethereal and alcoholic extracts were tested against cestodes, trematodes and nematodes and it was found that the drug taenicide acts both in vitro and in vivo $[48,49]$.The anthelmintic activity of the powder has been investigated in rats naturally infested with Taenia solium. The resin in 60 and $120 \mathrm{mg} / \mathrm{kg}$ dose exhibited lethal anthelmintic affects $(35.69 \%$ and $78.2 \%$ respectively) on the population of $[46,50]$. Kamala powder was found to be effective in Hymenolepiasis in childhood; $96 \%$ patients were cured after single dosage for 2 days. Besides acting on worms in the intestinal lumen, the drug also acts on the cysticercoids stage lodging in the intestine according to Sharma and Varma [13].

\section{$>$ Antiallergic Activity of Mallotus philippinensis \\ M. philippinensis fruit contains two new phloroglucinol derivatives, phloroglucinol derivatives and which inhibits histamine release from rat peritoneal mast cells induced by compound 48/80. This study suggests its anti-inflammatory activity. Rottlerin has been tested in animal models of IgE- dependent anaphylaxis and the antiallergic mechanisms of action in mast cells. Antiallergic action of rottlerin has been tested in passive cutaneous anaphylaxis and passive systemic anaphylaxis mouse models and in anaphylactic contraction}


of bronchial rings isolated from sensitized guinea pigs. These experiments prove antiallergic effect of rottlerin by blocking IgE-induced mast cell degranulation. This report suggests the use of rottlerin in mast cell-mediated allergic disorders including urticaria and allergic asthma [51].

\section{> In Vitro Cytotoxicity against Human Cancer Cell of Mallotus philippinensis}

Glandular hair extract of Mallotus fruit powder was assayed against 14 human cancer cell lines among different fractions; 95\% ethanolic extract showed the highest cytotoxic effect as compared to $50 \%$ ethanolic and aqueous portion. Further, the chromatographic analysis of the said fraction afforded a polyphenolic molecule rottlerin in Mallotus plant [13].

Fruit and bark of plant contain condensed tannins responsible for antioxidant activity. Some novel chalcone derivatives, $M$. philippensis $\mathrm{C}, \mathrm{D}$, and $\mathrm{E}$ were isolated from the fruits of $M$. philippinensis. Mallotoxin or rottlerin has great anti-cancerous potential. Among the ever-anticancer agents, rottlerin appears to have great potentiality for being used in chemotherapy. Rottlerin will become a potential molecule for research in future to treat cancerous cell as it will affect cell machineries involved in apoptosis, survival, and auto-phage. This suggests the view that this species has potential to be a beneficial chemotherapeutic remedy [52].

\section{$>$ Antitumor Activity of Mallotus philippinensis}

Four known friedelane-type triterpenoids, friedelin, 3-hydroxy-D:A-friedoolean-3-en-2-one, $\quad 2 \beta$-hydroxy-D:Afriedooleanan-3-one, and 3 $\alpha$-hydroxy-D:A-friedooleanan2-one, and two known lupane-type triterpenoids, lupeol and betulin were isolated from the bark of $M$. philippensis and were tested for their inhibitory effects on EpsteinBarr virus early antigen (EBV-EA) activation induced by 12-0-Tetradecanoylphorbol-13-acetate (TPA). The inhibitory effect of compounds 2 ( $\mathrm{IC}_{50}=292 \mathrm{~mol}$ ratio $/ 32 \mathrm{pmol} / \mathrm{TPA}$ ) and $4\left(\mathrm{IC}_{50}=288\right)$ was stronger than those of the other compounds tested and the positive control, curcumin $\left(\mathrm{IC}_{50}=\right.$ 343). Compound 3 $\alpha$-hydroxy-D:A-friedooleanan-2-one strongly inhibited mouse skin tumor promotion in an in vivo two-stage carcinogenesis model. Further, Rottlerin regulates multiple signalling pathways to suppress tumour cell growth in different types of cancer cells, though the complete mechanisms are still unclear.

\section{$>$ Hypoglycemic activity of Mallotus philippinensis}

Extract of fruit was found to possess hypoglycemic activity when tested on albino rats. A single dose of $250 \mathrm{mg} /$ $\mathrm{kg}$ was used and the estimation of sugars found that this drug along with other indigenous drug produces hypoglycemia in dogs [53].

\section{$>\quad$ Wound healing property of Mallotus philippinensis}

Many local communities still employ traditional formulations prepared from fruits, bark and the whole plant for treating wounds. Evidences are available for the wound healing activity of bark and fruits extracts of this plant. For instance, the ethanolic extract of bark enhanced the mobilization of mesenchymal stem cells towards the wounded areas possibly due to the effects of Cinnamtannin B-1 in a diabetic mouse model [54]. Similarly, the bark extracted in aqueous ethanol had the ability to attract mesenchymal stem cells thus effective against tissue injuries and this potential of the tree was granted a patent also [55]. Another study showed that the fruit glandular hair extracts stimulated collagen synthesis, anti-oxidant effects through peroxidase enzymes and inflammatory cytokines in rats [56]. Thus, it seems that it has the potential to effectively heal wounds, though specific potent compounds that have not been isolated and developed, yet.

\section{$>$ Mallotus philippinensisas a colouring agent}

Natural dyes play an important role in the livelihood of local and rural people. The granules which cover the ripe fruit are employed in India as a dye known as 'kamala' which is bright orange in colour and used as a dyeing silk and wool. Fresh fruits are known to yield about 1.4\%-3.7\% red powder containing pigment Rottlerin [57]. A patent has also been granted for describing the method of extraction of the dye from the fruit-pericarp containing readily watersoluble rottlerin [58]. The red dye obtained from the tree is frequently used for preparing traditional Bhutanese fabrics and colouring silk clothes [59]. This dye along with a mordant (Alum) is used for dyeing silk and wool [57,60]. This dye is believed to be superior for woolen and silk fabrics [61].

A red dye has been extracted from the roots. A study revealed that is used as a coloring agent for hydrogenated vegetable oils and its toxicity was studied on white rats and found no histological changes in the structure of liver, kidney and suprarenal's of rats examined at different intervals (one or half month.3 and 6 month) indicated the absence of toxicity of the drug even when given in fairly high concentration [62].

\section{Healthbenefits of Mallotusphilippinensis contain medicines}

\section{$>$ Wound healing and Antibacterial activity of Vipadikahara grita taila}

Following are some positive scientific aspects of $M$. philippinensis;

- The efficacy of Vipadikahara grita taila against Vipadika a skin disease (fissures of palms and feet with severe pain): a clinical study was scientifically proven by Hewageegana and co-workers [63]. 
- Vipadikahara grita taila showed potent antibacterial activity against Streptococcus pyogenes, by agar well diffusion method by measuring the zone of inhibition [64].

\section{$>$ Different preparations mention in Ayurveda Texts with their Recipes}

A single herb is rarely administered to a patient in Ayurveda and generally a formula made up of several herbs is used. They are always given with other foods or herbal items, e.g., honey, ghee, ginger, etc., which help mitigate toxicity and may increase absorption of certain ingredients, thus obtaining the desired therapeutic effect. Herbal formulae are favored in Ayurveda because the founders of Ayurveda recognized the possible synergistic and counter-balancing effects of herbs. There are several thousand formulae described in Ayurvedic texts that are recommended for over 200 well-identified diseases. Although M. philippinensis is a herbal drug because it is included under Sadharana rasa. It is observed that the drug is used in 44 formulation indicated in Krimiroga (worm infection), Twacha roga (skin disease), Shula (painful conditions), Shleshmodara (disease with phlegm in abdominal region), Premeha (is a syndrome described in the ancient Ayurvedic texts that include clinical conditions involved in obesity, prediabetes, diabetes mellitus and metabolic syndrome) etc. Useful part of the plant is Phalaraja (Glands and hair of the fruits) and should be administered internally after passing through Shodhana (purification) process [65].

However, Ayurveda provides guideline to minimize possible side effects by taking care of some guideline; which suggests time of drug administration, relationship of drugs with food, food which should be avoided with specific drug and drugs which should not be consumed together. Accordingly, Kampillaka must not be consumed with buttermilk [66]. Following Ayurveda medicines with their recipes are mentioned in Ayurveda authentic texts and they use for Ayurveda treatments. Recipes and uses with references are as follows Table 3:

\begin{tabular}{|c|c|c|c|c|}
\hline Kalpa (form) & Yoga (formulation) & Adhikarana & $\begin{array}{c}\text { External / } \\
\text { Internal }\end{array}$ & Reference \\
\hline \multirow{4}{*}{ Churna (powder) } & \multirow{4}{*}{ Kampillaka churna } & Gulma & I & $\mathrm{BP}$ \\
\hline & & Pittajagulma & $\mathrm{I}$ & $\mathrm{VM}$ \\
\hline & & Udavartha & $\mathrm{I}$ & SS \\
\hline & & Krimi & $\mathrm{I}$ & $\mathrm{BR}$ \\
\hline & \multirow{8}{*}{$\begin{array}{c}\text { Kampillakachurna+guda Kampillkadichurna } \\
\text { Shyamadichurna Patoladhichurna } \\
\text { Kushtadichurna Patolamuladyachurna } \\
\text { Tratyadhichurna Veerechaka yoga }\end{array}$} & Krimiroga & $\mathrm{I}$ & $\mathrm{BP}$ \\
\hline & & Prameha & $\mathrm{I}$ & $\mathrm{CS}$ \\
\hline & & Gulma & $\mathrm{I}$ & SS \\
\hline & & visha Gulma & $\mathrm{I}$ & $\mathrm{AH}$ \\
\hline & & Kushta & $\mathrm{I}$ & $\mathrm{CS}$ \\
\hline & & Udara & $\mathrm{I}$ & $\mathrm{CS}$ \\
\hline & & Trimarmiya & $\mathrm{I}$ & $\mathrm{CS}$ \\
\hline & & Samsodaneya & $\mathrm{I}$ & SS \\
\hline \multirow{4}{*}{ Yogas } & Kampillaka yoga & Sthilvakakalpa & $\mathrm{I}$ & $\mathrm{CS}$ \\
\hline & Shaladi yoga & Prameha & $\mathrm{I}$ & $\mathrm{AH}$ \\
\hline & Vidangothyadi yoga & Gulma & I & SS \\
\hline & Veerechanakaraka yoga & Shodhanagana & $\mathrm{I}$ & $\mathrm{AH}$ \\
\hline \multirow{5}{*}{ Vati (tablet) } & \multirow{5}{*}{$\begin{array}{c}\text { Krimighatinigutika, Gaganagarbhavati } \\
\text { Krimikutara rasa Pittajagulamahara yoga } \\
\text { Mahakalka rasa }\end{array}$} & Krimi, shotha. & I & $\mathrm{BR}$ \\
\hline & & Udara & $\mathrm{I}$ & RS \\
\hline & & gulma Krimi & $\mathrm{I}$ & RS \\
\hline & & Gulma & $\mathrm{I}$ & RS \\
\hline & & Vruna & $\mathrm{E}$ & RS \\
\hline Gutika & Kampillakadigutika & Virechaniya & $\mathrm{I}$ & SS \\
\hline Varti & Krumignadivarti & Krimi & I & CS \\
\hline
\end{tabular}


Journal of Natural \& Ayurvedic Medicine

\begin{tabular}{|c|c|c|c|c|}
\hline \multirow{8}{*}{ Ghrita(ghee) } & Triphaladyaghrita & Krimi & $\mathrm{I}$ & $\mathrm{BR}$ \\
\hline & Bindu ghrita & Udara & $\mathrm{I}$ & $\mathrm{BR}$ \\
\hline & Brhamighrita & Vatavyadhi & $\mathrm{I}$ & $\mathrm{BR}$ \\
\hline & Nilinighrita & Gulma, kushta & $\mathrm{I}$ & $\mathrm{CS}$ \\
\hline & Vipadikaharaghrita & Kushta,vipadika & $E$ & $\mathrm{CS}$ \\
\hline & Dhanvantaraghrita & Prameha,vruna & $\mathrm{I}$ & $\mathrm{AH}, \mathrm{SS} \mathrm{SS}$ \\
\hline & Tilvakaghrita & Vata vyadhis & $\mathrm{I}$ & $\mathrm{AH}$ \\
\hline & Kampillakadighrita & Gulma & $\mathrm{I}$ & \\
\hline \multirow{9}{*}{ Taila (oil) } & \multirow{9}{*}{$\begin{array}{c}\text { Kampillaka taila Kushtadyataila Kanaka } \\
\text { ksheeritaila Vipadikaharataila Kampilladikataila } \\
\text { Kampillakaditaila Mahavajrakataila } \\
\text { Jeevantyadhitaila Phalataila }\end{array}$} & Vruna & $E$ & $\mathrm{CS}$ \\
\hline & & Kushta & $E$ & $\mathrm{CS}$ \\
\hline & & Kushta & $E$ & $\mathrm{CS}$ \\
\hline & & Kushta & $E$ & $\mathrm{CS}$ \\
\hline & & Visarpa & $E$ & $\mathrm{CS}$ \\
\hline & & granti Dwivruniya & $E$ & $\mathrm{CS}$ \\
\hline & & Kushta & $E$ & $\mathrm{AH}, \mathrm{SS} \mathrm{AH}$ \\
\hline & & $\begin{array}{l}\text { Nadivrun Gulma } \\
\text { Kushta }\end{array}$ & I & SS \\
\hline & & krumi & $\mathrm{I}$ & \\
\hline $\begin{array}{c}\text { Malahara } \\
\text { (ointment) }\end{array}$ & Kampillakamalahara & Kustha, visarpa & $\mathrm{E}$ & RS \\
\hline Bhasthi & Shodhanabhasthi & Basthi siddhi & $\mathrm{I}$ & $\mathrm{CS}$ \\
\hline \multirow{2}{*}{ Avachurnana } & \multirow{2}{*}{ Musthakadhiavachurna Guggulyadigarshana } & Vruna & E & $\mathrm{AH}$ \\
\hline & & Prameha & $\mathrm{E}$ & $\mathrm{AH}$ \\
\hline Kalka & Kampillkakalka & Prameha & $\mathrm{I}$ & SS \\
\hline
\end{tabular}

Table 3: External and internal reference of kalpa and yoga form.

AH- Ashtanghahrudaya SS - Sushrutasamhita

CS - Charakasamhita BP - Bhavaprakasha

BR - Bhaishajya ratnavali RS- Rasashastra

VM- Vrundamadhava

1. Gulma (different kind of abdominal lump),

2. Udavarta (reverse movement of Vata),

3. Krimi (worms)

4. Udara (generalized distension or enlargement of abdomen of any etiology)

\section{Mallotus philippinensiscontains Medicated powders (Churna)}

\section{$>$ Recipes and the dosage for some diseases:}

\section{- Kampillaka Churna}

A weight of $5 \mathrm{~g}$ of M. philippinensis powder should be measured, and it should be taken with $10 \mathrm{~g}$ of guda (jaggery) daily. This medication clears the intestine of the worms without doubt [8].

\section{- Patolamuladi Churna}

Patola roots, Haridra, Vidanga, Pulp of Amalaki, Haritaki and Vibhitaki, Kampillka, Nilini and trivrut. First six $10 \mathrm{~g}$ (01 part each) each. The nest three 20g (two parts), Nilini three parts and Trivrut 4 parts. All these drugs is made to powders and given to the patient along with $40 \mathrm{~g}$ of cow's urine this cause purgation. Thereafter the patient is given light food along with meat soup of wild animals. After taking rice and liquid gruel, patient should be keep on milk boiled with trikatu for six days. Again should take this powder. In this way it should be repeated. This powder eradicates all types of Udara roga even after appearance of fluid. It is also a remedy for jaundice, anaemia and oedema. This powder is used in abdominal disorders (udara) in Caraka Samhita.

One suffering from Prameha caused by Kapha and pitta should take powder of the flowers of Kampillaka, Saptaccada, Shalavibhitaka, rohitaka, kutaja and kapittha. These may also 
be taken as paste in the dose of $10 \mathrm{~g}$ along with Amalaka juice in time. After the drug is digested it should take food of old cereals along with delicious meat soup of wild animals according to Caraka Samhita.

\section{Mallotus philippinensiscontains oils [Taila (Medicated oil), Gruta (Medicated ghee) or Malahara (ointment)]}

\section{> Vipadikahara grita taila for Vipadika skin lesion}

Vipadikahara ghrita taila contains four medicinal plants [Leptadenia reticulata (Retz) Wight and Arn., (Family: Asclapadaceae), Rubia cordifolia Linn Syst., (Family: Rubiaceae), Berberis aristata DC. Syst., (Family: Berberidaceae), Mallotus Philippensis (Lam.) Muell. Arg. (Family: Euphorbiaceae)], two liquids (cow's milk and the water), two oils (cow's ghee and Sesame oil), resin of Soria robusta Geartn.f. (S. robusta) and bee's wax [67]. Vip@ dik@hara gh=ta taila (VHGT)is an easy prepared, fragrant medicated oil which can be used externally to treat five types of skin diseases (K\&udra ku\&\{ha: Carmaku\&\{ha, Eka ku\&\{ha, Ki\{ibha, Alasaka and Vip@dik@) according to Ayurvedic authentic text Caraka Samhita [67]. A significant reduction of the symptoms such as itching, splitting and pain were identified as a result of its high medicinal value andVipadika kushtha treated with Vipadikahara grita taila displayed a significant improvement of wound healing and the oil is an effective, easily and applicable, successful, user friendly, pleasant odor medicated oil [63].

- Kampillaka, vidanga, Daruharidra, Karanja fruit all should be pounded and used or cooking an oil. This oil is efficacious in Granthi Visarpa. (Caraka Samhita, Chikitsa sthana, vol II, P V Sharma, Chaukambha Sanskrit Sansthan, India).

\section{Malahara (Ointment)}

"Kajjali Kodaya Malahara" for wound cleansing, healing and chronic wounds for quick healing activity are some examples which were mentioned in Ayurveda classics. Availability of these prepared medicines is less in market in Sri Lanka.

\section{Mahavajraka taila}

The drugs and substances known as white mustard-seeds (Brassica nigra), the two kinds of Karanja (Millettia pinnata (L.), the two kinds of Haridra (Curcuma longa) and Coscinium fenestratum) etc including M. philippinensis should be taken in equal parts and made into a paste. This paste (Kalka) should be cooked with either Karanja-oil (Millettia pinnata) or mustard-oil; both having great curative potency, with double the quantity of cow's urine. It may also be prepared with sesamum-oil, but in this case four times as much of cow's urine should be taken. As an anointment it is undoubtedly efficacious in a case of Kushtha (skin lesions) of whatso ever type as well as in cases of scrofula, fistula-in- ano, sinus and malignant ulcers. This oil is known by the name of MahaVajraka oil and is possessed of supreme and unquestionable efficacy.

\section{Ghrita}

Triphaladya ghritam: It contains Murchita ghrita (Ghrita Murchana is a special pharmaceutical preparation procedure before subjecting the drugs), Triphala (Emblica officinalis (Amalaki), Terminalia bellerica (Bibhitaki), and Terminalia chebula (Haritaki), Trivrut (Operculina turpethum), Danti (Baliospermum montanum), Vacha (Acorus Calamus Herb), Kampillaka (M. philippinensis) and cow's urine.

Murchita gruta (1 kg) should be boiled with kalka (paste) of above ingredients (each $50 \mathrm{~g}$ ) along with cow's urine (4 L). Taking of this medicated Gruta destroys parasites and worms [68].

\section{General Recipes of Mallotus Philippinensis (Kampillaka)}

- In worm infestations (Krimi)-Kampillaka fruits taken and powdered well. It is then taken internally at a dose of $5 \mathrm{~g}$ along with jaggery.

- In skin diseases (Kushtha)-Finely powdered Kampillaka is applied on skin along with ghee. It can alleviate skin diseases.

- In diabetes (Prameha)-Decoction prepared with Kampillaka and Amalaki can be used to control diabetes.

- In wound (Vrana)-Oil processed with Kampillaka is applied on the skin. It can improve healing the wound.

- In Haematometra (Raktha gulma)-Kampillaka powder is mixed with sugar and honey and taken internally at a dose of $12 \mathrm{~g}$.

- In fever (Jwara)-Decoction made with leaves of Kampillaka and Tulsi taken internally at a dose of $60 \mathrm{ml}$.

- In inflammation (Shopha)-Paste prepared from Kampillaka fruits is applied together with ghee all over the skin part.

- In renal calculi (Asmari)-Oral intake of decoction prepared from the leaves of Kampillaka at a dose of 60 ml per day will control Asmari.

\section{Showing different shodhana procedure mentioned for Kampillaka}

Kampillaka is subjected to bhavana with juices of matulunga (citrus medica Linn) and ardraka (ginger) for 3 times. Rasajalanidhi [69]. Kampillaka is purified by boiling it with haritakikashaya (decoction of Terminalia chebula) or 
Kanji (gruel) by means of dolayantra Basaavarajeeyam [70]. A weight of $500 \mathrm{gm}$ of Kampillaka is mixed in 10 liters of water \& rubbed using both hands for about 5 minutes. So that pure Kampillaka will float on the water and the adulterated brick powder will settle down in water [71].

\section{Discussion}

Clinical usage of the medicinal plants and its interests have been drastically increased over the past decades throughout the world, as well as their formulations are increasingly cited in media. M. philippinensis has been widely used in traditional medicine in several parts of countries including India and Sri Lanka. Along with this medicinal importance, this plant is used against human pathogens including $\mathrm{H}$. pylori, antiinflammatory activity, antioxidant, antiradical, protein inhibition, hepatoprotective, antiallergic, anti-HIV activity and many more. Phytochemical investigation revealed that a large number phenol derivatives and several miscellaneous compounds from different classes have been isolated from this species. The phenols, diterpenoids, steroids, flavonoids, cardenolides, triterpenoids, coumarins and iso-coumarins are mostly distributed in all parts of the plant [72-80].

\section{Conclusion}

Present review confirms the medicinal values of Mallotus philippensis and it can be used against human pathogens and a promising candidate for hepatoprotection, antileukaemic, anti-HIV, anti-inflammatory, analgesic, hypnotic, antioxidant potential and healing skin lesions and many more. These findings may lead to further development of novel pharmaceutical preparations from M. philippensis in the future.

Literature search has shown that this plant has immense medicinal \& economic uses in different systems of Medicine in India as well as throughout the world [80-91]. Though it has such medicinal \& economic property it is now rarely available and has been categorized as an endangered plant could be unawareness about its uses in general public as well as its difficulty in natural reproduction, so different methods of its conservation \& propagation should be adapted so as to prevent its extinct (Figure 5).

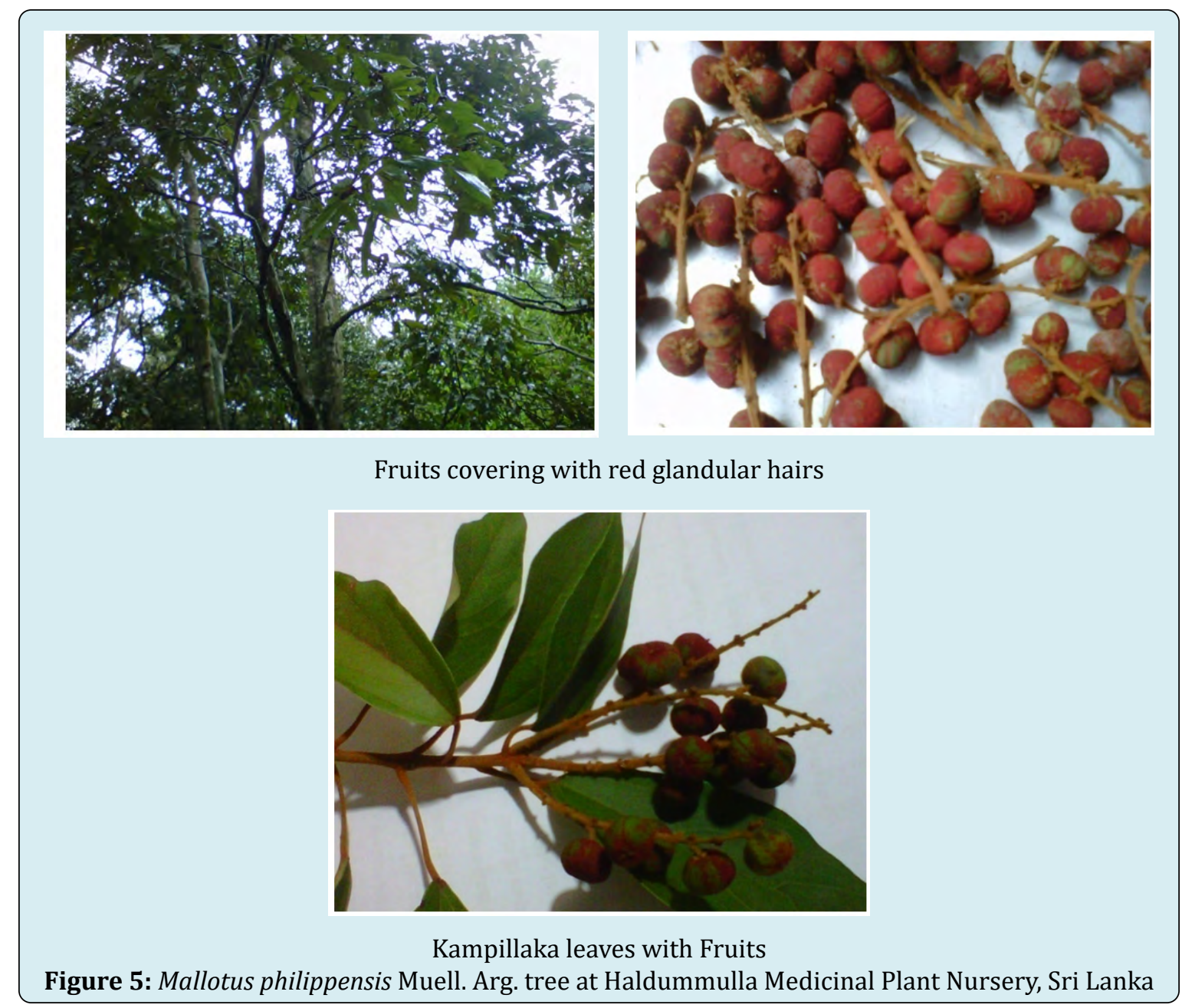




\section{References}

1. Bhavamishra (2006) Bhavaprakashanighantu, Commentary by Chunekar KC, et al. chaukhamba bharati academy, varanasi, pp: 66.

2. Trikamji J (2005) Sushruta, sushrutasamhita, with commentary of Dalhana, Sutrasthana, $38^{\text {th }}$ chapter/ 29 , chowkambha orientalia varanasi, pp: 166.

3. Usmanghani K, Saeed A, Alam MT (1997) Indusynic Medicine, Karachi. Research Institute of Indusyunic Medicine, pp: 285-287.

4. Orwa C, Mutua A, Kindt R, Jamnadass R, Anthony S (2009) Agroforestry Database: A tree reference and selection guide version 4.0.

5. Kirtikar KR, Basu BD (1996) Indian Medicinal Plants Vol 3 , Valley offset printers and Publishers, Dehradun, India, pp: 2267-2268.

6. Annonymus (1985) Ayurveda Pharmacopoeia, volume 1, Part 2, Department of Ayurveda, Navinna, Maharagama, pp: 96.

7. Paranjpe P (2005) Indian Medicinal Plants-forgotten Healer, Chaukhamba Sanskrit Pratishthan, Delhi, pp: 116.

8. Anonymous (1979) Ayurveda pharmacopoeia: volume1 part 2, Department of Ayurveda, Colombo, Sri Lanka, pp: 47- 49.

9. Gangwar M, Goel RK, Nath G (2014) Mallotus philippinensis Muell. Arg (Euphorbiaceae): Ethnopharmacology and Phytochemistry Review, BioMed Research International, Special issue.

10. Geetha KM, Ramakrishna S, Sridhar C, Murugan V (2011) Hepatoprotective activity of methanolic extract of Mallotusphilippensis [LAM.] Muell Arg leaves in rats. April Asian Journal of Chemistry 23: 1577-1580.

11. Senagupta S, Sengupta SB (1991) Caraka Samhita, Vol IIINidanasthana, Cikitsasthana, Chaukhambha Orientalia, Varanasi.

12. Anonymous (2001) Agnivesha-Caraka samhita, Revised by Caraka and Drudabhala, with commentary of Cakrapaneedatta, $5^{\text {th }}$ (Edn.), edited by Jadavji Trikamji, Choukamba Sanskrit Sanstan, Varanasi.

13. Sharma, Varma (2011) A Review on Endangered plant of Mallotus philippensis (Lam.) M Arg Pharmacologyonline 3: 1256-1265.
14. (2010) Ramakrishna is reported by Hepatoprotective activity of methanolic extract of Mallotus philippensis [LAM.] Muell Arg leaves in rets.

15. (2009) Agro-Forestry Tree Data Base Literatures.

16. Zafar R (1994) Medicinal Pants of India.

17. Anonymous (2003) The wealth of India, A Dictionary of Indian Raw materials \& industrial products. First supplement series (raw materials), NISCAIR.

18. Velanganni J, Kadamban D, Tangavelou AC (2011) Phytochemical screening and antimicrobial activity of the stem of Mallotus Philippensis (Lam.) Muell Arg Var Philippensis (Euphorbiaceae). International Journal of Pharmacy and Pharmaceutical Sciences 3: 333.

19. Ahmad F, Hashmi S (1995) Adulteration in commercial Kamila (Mallotus philippinensis Muell.) an anthelmintic drug of repute. Hamdard Medicus 38: 62-67.

20. More DB, Giradkar PS (2020) Herbal Drug Adulteration: A Hindrance to the Development of Ayurveda Medicine. International Journal of Ayurvedic \& Herbal Medicine $10(2)$.

21. Hewageegana HGSP, Arawwawala LDAM, Tissera MHA, Ariyawansa HAS, Dhammarathna I (2014) A comparison of the physico-chemical and phytochemical parameters of glands/hairs of fruits and leaves of Mallotus. Journal of National Science Foundation, Sri Lanka 42(3).

22. WHO (2000) General Guidelines for Methodologies on Research and Evaluation of Traditional Medicine, World Health Organization, Geneva.

23. Kokate CK, Purohit AP, Gokhale SB (2006) Text book of Pharmacognosy, Nirali, Prakashan, Pune, pp: 109-133.

24. Mukherjee PK (2002) Quality Control of Herbal Drugs., India: Business Horizons; New Delhi.

25. Vijay KP, Laxman BC, Bansilal SS, Ashok RS (2013) Pharmacognostical Evaluation of Fruits of Mallotus Philippenensis (Lam). Muell- Arg (Euphorbiaceae). Journal of Pharmaceutical and Scientific Innovation 2(3): 20-23.

26. Ayyanar M, Ignacimuthu S (2005) Traditional knowledge of kani tribals in kouthalai of tirueveli hills, Tamil Nadu. India Journal of ethnopharcology 102(2): 246-255.

27. Han X, Shen T, Lou H (2007) Dietry polyphenols and their biological significance. International Journal of Molecular Sciences 8(9): 950-988. 
28. Ali SS, Kasoju N, Luthra A, SinghA, Sharanabasava H, et al. (2008) Indian medicinal herbs as source of antioxidants. Food Res Int 41(1): 1-15.

29. Marjorie C (1996) Plant products as antimicrobial agents. Clincal Microbiol Rev 12(4): 564-582.

30. Just MJ, Recio MC, Giner RM, Cueller MU, Manez S, et al. (1998) Anti-inflammatory activity of unusual lupane saponins from Bupleurum fruticescens. Planta Med 64(5): 404-407.

31. Lewis HW, Moody CJ (1989) Experimental Organic Chemistry: Principles and Practice. Wiley Blackwell, pp: 159-173.

32. Kumar VP, Chauhan NS, Padh H, Rajani M (2006) Search for antibacterial and antifungal agents from selected Indian medicinal plants. Journal of Ethnopharmacology 107(2): 182-188.

33. Moorthy K, Srinivasan K, Subramanian C, Mohanasundari C, Palaniswamy M (2007) Phytochemical screening and antibacterial evaluation of stem bark of Mallotus philippinensis var. Tomentosus. African Journal of Biotechnology 6(13): 1521-1523.

34. Zaidi SFH, Yoshida I, Butt F, Yusuf MA, Usmanghani K, et al. (2009) Potent bactericidal constituents from Mallotus philippinensis against clarithromycin and metronidazole resistant strains of Japanese and Pakistani helicobacter pylori. Biological and Pharmaceutical Bulletin 32(4):631636.

35. Honga Q, Mintera DE, Franzblaub SG, Arfanc M, Aminc H, et al. (2010) Anti-tuberculosis Compounds from Mallotus philippinensis. Natural Product Communications.

36. Khan M, Qureshi RA, Hussain M, Mehmood K, Khan RA (2013) Hexane soluble extract of Mallotus philippinensis (Lam.) Muell.Arg. root possesses anti-leukaemic activity. Chemistry Central Journal 7(1): 157.

37. Ramakrishna S, Geetha KM, Bhaskar Gopal PVVS, Kumar RP, Madav CP, et al. (2011) Effect of Mallotus Philippinensis Muell.-Argleaves against hepatotoxicity of Carbon tetrachloride in rats. International Journal of Pharmaceutical Sciences and Research 2(2): 74-83.

38. Nakane H, Arisawa M, Fujita A, Koshimura S, Ono K (1991) Inhibition of HIV-reverse transcriptase activity by some phloroglucinol derivatives. FEBS Letters 286(12): 83-85.

39. Taylor RS, Hudson JB, Manandhar NP, Towers GH (1996) Antiviral activities of medicinal plants of southern Nepal. J Ethnopharmacol 53(2): 97-104.
40. Gangwar M, Gautam MK, Ghildiyal S, Nath G, Goel RK (2016) Pharmacological evaluation of Mallotus philippinensis (Lam.) Muell. Arg. fruit hair extract for anti-inflammatory, analgesic and hyponic activity. Journal of Intercultural Ethnopharmacology 5(1): 14-21.

41. Katsuki SD, Kitanaka S (2004) Antiallergic agents from naturalsources, Inhibition of nitric oxide production by novel chalcone derivatives from Mallotus philippinensis (Euphorbiaceae). Chemical \& Pharmaceutical Bulletin 52(11): 1326-1329.

42. Singh R, Singhal KC, Khan NU (1997) Antifilarial activity of Mallotusphilippinensis Lam. on Setariacervie (Nematoda: Filarioidea) in-vitro. Indian Journal of Physiology and Pharmacology 41(4): 397-403.

43. Arfan M, Hazrat K, Magdalena K (2009) Antioxidant activity of phenolic fractions of Mallotus philippinensis bark extract. Journal of Food Science 27(2): 109-117.

44. Thakur SC, Thakur SS, Chaube SK, Singh SP (2005) An etheral extract of Kamala (Mallotus philippinensis (Moll. Arg) Lam.) seed induce adverse effects on reproductive parameters of female rats. Reproductive Toxicology 20(1): 149-156.

45. Gujral M, Verma RD, Sareen KN (1960) Preliminary observation on the antifertility effect of some indigenous drug. Ind J Med Res 48: 46-58.

46. Gupta SS, Verma P (1984) Purgative and anthelmintic effects of M.philippinensis in rats against tapeworms. Ind J Physiol Pgarmacol 28(1): 63-66.

47. Hussain A, Khan MN, Iqbal Z, Sajid MS (2008) An account of the botanical anthelmintics used in traditional veterinary practices in Sahiwal district of Punjab, Pakistan. Journal of Ethnopharmacology 119(1): 185190.

48. Bever BO (1983) Anti-infection therapy with higher plants. J Ethno Pharmacol 9(1): 1-83.

49. Shrivastava MC, Singh SW, Tiwari JP (1967) Anthelmintic activity of kambila powder. Ind J Med Res 55(7): 746748.

50. Verma P, Gupta SS, Aggarwal S (1981) Purgative and anthelmintic activity in Mallotus philippenesis. Ind J Phrmacol 13(1): 103.

51. Chan TK, David SW, Cheng C, Guan SP, Koh HM, et al. (2013) Anti-allergic actions of rottlerin from $M$. philippinensis is in experimental mast cell-mediated anaphylactic models. Phytomedicine 20(10): 853- 860. 
52. Gangwar M, Goel RK, Nath G (2014) Mallotus philippinensis Muell. Arg (Euphorbiaceae): Ethnopharmacology and Phytochemistry Review. Bio Med Research International, pp: 1-14.

53. Ainapure SS (1985) Hypoglycaemic activity of an indigenous preparation. Ind J Pharmacol 17(4): 238239.

54. Furumoto T, Ozawa N, Inami Y, Toyoshima M, Fujita K, et al. (2014) Mallotus philippinensis bark extracts promote preferential migration of mesenchymal stem cells and improve wound healing in mice. Phytomedicine 21(3): 247-53.

55. Kitamura K, Inami Y, Nakaoji K, Hamada K, Maeda A, et al. (2016) Mesenchymal stem cell attractant and method for attracting mesenchymal stem cell. Patent.

56. Gangwar M, Gautam MK, Ghildiyal S, Nath G, Goel RK (2015) Mallotus philippinensis Muell. Arg fruit glandular hairs extract promotes wound healing on different wound model in rats. BMC Complement Altern Med 15: 123.

57. Siva R (2007) Status of natural dyes and dye-yielding plants in India. Curr Sci 92(7): 916-25.

58. Maeda M, Fukami H, Namikawa K (2009) Method for producing Mallotus philippinensis dye composition and the composition.

59. Tshering S (2009) Natural Vegetable Dyes; Food, Fruit Species and Mushrooms; Gums and Waxes; and Incense. In: Non-Wood Forest Products of Bhutan. Bangkok, Thailand: Food

60. Rao VS, Seshadri TR (1947) Kamala dye as an anthelmintic. Proceedings of the Indian Academy of Sciences. Section A 26(3): 178-181.

61. Gaur RD (2008) Traditional dye yielding plants of Uttarakhand, India. Nat Prod Radiance 7(2): 154-165.

62. Gupta JC, Chatterjee MC (1946) Kamala as a colouring agent for hydrogenated vegetable oils: Its toxicity on white rats. Sci Cult 11(7): 375-377.

63. Hewageegana HGSP, Ariyawansa HAS, Arawwawala LDAM (2019) Clinical study on the efficacy of Vipadikahara Grita Taila on the treatment of Vipadika Skin Disease. Journal of Dermatology and Dermatopathology.

64. Hewageegana HGSP, Arawwawala LADM, Kottahachchi J, Athukorala GIDDAD, Weerasekera MM (2013) Standardization and Evaluation of the Antibacterial activity of Vipadikahara grita taila. International
Conference on Ayurveda Unani Siddha and Traditional Medicine.

65. Mhasal SS, Chondikar S (2018) Comparative Study of Antimicrobial Activity of 2 Different Formulation of Kampillaka (Mallotus Philippensis) i.e. Kampillaka Oil and Kampillaka Malhara. Journal of Ayurveda, Herbal Medicine and Innovative Research 3(2): 01-06.

66. Vaidya CH (2018) Ayurveda perspective of natural drug interaction: A Literature Review. World Journal of Pharmaceutical and Medical Research 4(5): 171-173.

67. Senagupta N (1855) Caraka Samhita (Vol 3Cikitsasthana) Sri Rangalalaminnena press, India.

68. Das SG (2016) Baisajja ratnavali, vol 1, Krimi chikitsa, Chaukambha Sanskrit Sansthan, India.

69. Mookerjee B (2004) Rasajalanidhi, $3^{\text {rd }}$ chapter, chaukhamba orietalia, varanasi, pp: 212.

70. Neelakanta KB (2007) Basavarajeeyam, hindi translation by V. Rangacharya, $25^{\text {th }}$ chapter/181, Bharateeya Ayurvijnana It has Sansthan, Hyderbad, pp: 886.

71. Nishteswar K, Vaidyanath R (2005) Ayurvedeeya Rasashastra, $10^{\text {th }}$ Chapter, chaukhamba surabharati prakashan varanasi, pp: 162 .

72. Kumar A, Patil M, Kumar P, Bhatti RC, Kaur R, et al. (2021) Mallotus philippensis (Lam.) Müll. Arg.: A review on its pharmacology and phytochemistry. J Herbmed Pharmacol 10(1): 31-50.

73. Trikamji JA (2009) Charakasamhita, with commentary of Chakrapanidatta.

74. Adhav M (2015) Phytochemical screening and antimicrobial activity of Mallotus philippensis Muell. Arg. Journal of Pharmacognosy and Phytochemistry 3(5): 88191.

75. Kampillaka A, Samhita C (2001) Revised by Charaka and Dridhabala, with commentary of Chakrapanidatta, edited by Trikamji J, Varanasi, $5^{\text {th }}$ (Edn.), Chowkambha Sanskrit Sansthan.

76. (1996) Agriculture Organization of the United Nations, pp: 87-106.

77. Kotrannavarn VKS, Angadi SS, (2013) A Review of kampillaka (Mallotus Philippinensis Muell) from ayurvedic perspective. Annals of Ayurvedic Medicine 2(3): 89-98.

78. Arfan M, Amin H, Karamac M, Kosińska A, Shahidi F, et 
al. (2007) Antioxidant activity of extracts of Mallotus philippinensis fruit and bark. Journal of Food Lipids 14(3): 280-297.

79. Bhavaprakasha (2000) Krimichikitsa B Edited with Vidyotini Hindi Commentary by Brahma Sankara Misra, Varanasi, $7^{\text {th }}$ (Edn.), Chaukambha Sanskrit Sansthan.

80. (2000) Chikitsasthana $5^{\text {th }}$ chapter/105, chowkambha sanskrit sansthan varanasi, pp: 441.

81. Sharma J, Varma R (2011) A Review on Endangered plant of Mallotus philippensis (Lam.) M. Arg. Pharmacologyonline 3: 1256-1265

82. Sharma PV, Samhita C (2010) Chikitsa sthana, vol II, Chaukambha Sanskrit Sansthan, India.

83. Singh R, Singhal KC, Khan NU (1997) Antifilarial activity of Mallotus philippinensis Lam. on Setaria cervie (Nematoda: Filarioidea) in-vitro. Indian Journal of Physiology and Pharmacology 41(4): 397-403.

84. Tanaka R, Nakata T, Yamaguchi C, Wada S, Yamada T, et al. (2008) Potential anti-tumor-promoting activity of $3 \alpha$-Hydroxy-D: a-friedooleanan-2-one from the stem bark of Mallotus philippinensis. Planta Medica 74(4): 413-416.

85. Gupta SS, Verma P, Hishikar K (1984) Purgative and anthelmintic effects of Mallotus philippinensis in rats against tapeworm. Indian Journal of Physiology \& Pharmacology 28(1): 63-66.

86. Sukhadiya CAM, Behera LK, Mehta AA, Patel SM, Bhusara J (2019) Mallotus philippinensis: Overall outlook of a multipurpose medicinal tree, Van Sangyan.

87. Trikamji J (1980) Kampillaka, Sushruta Samhita, with commentary of Dalhana, edited by Varanasi; Chowkambha Orientalia.

88. Tripathi IP, Chaudhary P, Pandey P (2017) Mallotus Philippensis: a miracle stick. World Journal of Pharmaceutical Research 6(7): 678.

89. Sharma V (2011) A polyphenolic compound rottlerin demonstrates significant in vitro cytotoxicity against human cancer cell lines: isolation and characterization from the fruits of Mallotus philippinensis. Journal of Plant Biochemistry and Biotechnology 20(2): 190-195.

90. Kotrannavar VKS, Angadi SS, (2013) A Review of Kampillaka (Mallotus Philippinensis Muell) From Ayurvedic Perspective. Annals of Ayurvedic Medicine 2(3): 89-98.

91. Kotrannavar VKS, Angadi SS (2013) A Review Of Kampillaka (Mallotus Philippinensis Muell) From Ayurvedic Perspective, Wealth of India,Vol: 9-32, C.S.I.R. Publication. 